\title{
Evaluation of Information Technologies Teachers' in-class Behaviors in the Context of Hidden Curriculum*
}

\author{
Mustafa Fidan**
}

\author{
Meriç Tuncel $^{* * *}$
}

\begin{abstract}
The aim of this study is to evaluate the in-class behaviors of information technologies teachers and the factors that lead to those behaviors in the context of hidden curriculum on the basis of the opinions of information technologies teachers. From the qualitative research methods, the 'phenomonology' research design was used in this study. A total of 15 information technologies teachers who were teaching at secondary schools in a central town of a city located in the West Blacksea Region, Turkey, participated in the study. From purposeful sampling method, criterion and maximum diversity samplings were used in selection of the sample. Data were collected by means of semi-constructed interview forms. The gathered data were analyzed through both descriptive and content analysis methods. As a result of the interviews made with teachers, it was observed that the teachers gave messages and responses which were not in the scope of the formal curriculum. In this direction, teacher behaviours were divided into seven sub-themes such as "power and authority", "prejudices and discrimination", "narratives", "communication", "role-model", "getting a profession", and "school culture". It was identified that most of the teachers were authoritarian and serious, discriminated among students according to individual differences, conveyed the ideas that they did not adopt in real life, made social, moral and ideological narratives suiting with their own thoughts and beliefs, preferred teachercentered methods and techniques and were not able to create a democratical environment during lessons. In this study, it was understood that information technologies served to the hidden curriculum especially in terms of adoption of school culture, interaction with students was effective in occurance of hidden learnings, and status and economical advantages of a profession were of primary importance in teachers' professional guidance. Depending on the results of this study, some educational conclusions and recommendations for future studies were also included in this paper.
\end{abstract}

Keywords: hidden curriculum, information technologies, secondary school, curriculum, teacher's behaviours

\footnotetext{
* This study was derived from first author's master's thesis, conducted under the supervision of the second author.

*** Inst. Dr., Bartin University, Distance Education Application and Research Center, Bartin, Turkey. E-mail: mfidan@bartin.edu.tr

**** Assist. Prof. Dr., Bolu Abant İzzet Baysal University, Department of Educational Science, Bolu, Turkey. E-mail:tuncel_m@ibu.edu.tr
} 


\title{
Bilişim Teknolojileri Öğretmenlerinin Ders içi Davranışlarının Örtük Program Bağlamında Değerlendirilmesi
}

\begin{abstract}
$\ddot{\mathbf{O z}}$
$\mathrm{Bu}$ araştırmada bilişim teknolojileri öğretmenlerinin görüşlerinden hareketle, ders içi davranışlarının ve bu davranışların ortaya çıkmasında etkili olan unsurların örtük program bağlamında değerlendirilmesi amaçlanmıştır. Araştırmada nitel araştırma yöntemlerinden olgubilim (fenomonoloji) deseni kullanılmıştır. Araştırmaya Batı Karadeniz Bölgesi’nde bir ilin Merkez ilçesindeki ortaokullarda görev yapan 15 bilişim teknolojileri öğretmeni katılmıştır. Çalışma grubunun belirlenmesinde, amaçlı örnekleme yöntemlerinden ölçüt ve maksimum çeşitlilik örneklemesi kullanılmıştır. Araştırma verileri yarı yapılandırılmış görüşme formu aracılı̆̆ıla toplanmıştır. Elde edilen veriler, hem betimsel analiz hem de içerik analizi yapılarak çözümlenmiştir. Görüşmeler sonucunda öğretmenlerin resmi program dışında mesaj ve tepkiler verdikleri görülmüştür. Bu doğrultuda öğretmen davranışlarına yönelik "güç ve otorite", "ön yargılar ve ayrımcıllk", "anlatılar", "iletişim", "rol-model", "meslek edinme" ve "okul kültürü" olmak üzere yedi alt tema belirlenmiştir. Derste öğretmenlerin çoğunun; otoriter ve sert oldukları, bireysel farklılklara göre ayrım yaptıkları, gerçek yaşamda benimsemedikleri düşünceleri aktardıkları, kendi görüş ve inançlarına göre toplumsal, ahlaki ve ideolojik anlatılar yaptıkları, öğretmen merkezli yöntem ve teknikleri tercih ettikleri, demokratik bir ortam oluşturmadıkları tespit edilmiştir. Araştırmada biliş̧im teknolojilerinin özellikle okul kültürünü benimsemede örtük programa hizmet ettiği, öğrencilerle kurulan iletişimin gizil öğrenmelerin oluşmasında etkili olduğu, öğretmenlerin mesleki yönlendirmelerinde statünün ve ekonomik getirinin ön planda olduğu görülmüştür. Araştırma sonuçları doğrultusunda gelecekte yapılacak araştırmalara ilişkin önerilere ve eğitsel çıkarımlara yer verilmiştir.
\end{abstract}

Anahtar Sözcükler: örtük program, bilişim teknolojileri, ortaokul, öğretim programı, öğretmen davranışları 


\section{Introduction}

Behaviours that teachers display in educational settings are one of the important factors that shape teaching-learning process. During teaching practice, teachers might give verbal or nonverbal messages and responses in compliance with their own personality, thoughts, beliefs and expectations either being aware or not. According to Alsubaie (2015), teacher behaviours have impact on occurance of unplanned learnings out of the formal curriculum beside helping to reach the desired features by affecting the learning activities. This indicates that formal curriculum may not be applied as it has been planned in a real classroom setting and learning outcomes might be different from what is expected even if it has been prepared very cautiously and systematically (Yüksel, 2004). In this sense, students encounter the hidden curriculum which includes unwritten and unplanned learning outcomes out of the formal curriculum.

Hidden curriculum is a comprehensive concept which includes the unplanned activities that are not clearly stated in formal curriculum and the learnings that students are expected to achieve (Alsubaie, 2015; Murphy, Mufti \& Kossem, 2009; Yüksel, 2004). The hidden curriculum is defined by some researchers as learnings that occur through experiences rather than the goals planned in educational organizations (Dickerson, 2007); the hidden and unwanted messages transmitted to studens unconsciously (Leask, 2015); and a group of moral and norm-based learnings (Hopkins, Saciragic, Kim \& Posner, 2016). Jackson (1968) describes this concept as expectations, rules, values and norms which are not written in the formal curriculum but students are expected to learn by their parents and the school administrators. Theoretically, Skelton (1997) examines the hidden curriculum based on the functionalist, liberal, critical and post-modern view while Lynch (1989) examines it based on the structural-functionalist and neo-marxist view. On the other hand Karanxha, Agosto \& Bellara (2013) emphasized that hidden curriculum is related to critical pedagogy which has impact on discovery of the social functions in education. The most distinctive characteristic of hidden curriculum is that it is not written and it has a strong sociological aspect (Tezcan, 2003; Yüksel, 2004). Based on these definitions and explanations, all of the unplanned activities that have a positive or negative impact on students other than those stated in the formal curriculum can be defined as hidden curriculum.

\section{The Scope of Hidden Curriculum}

Hidden curriculum includes all of the unplanned activities other than the goals stated in formal curriculum. Since the scope of the hidden curriculum which differs according to learning setting (classroom, school, lesson and etc.) is too wide, to reveal the content of a hidden curriculum in detail is a challenging work (Alsubaie, 2015; Edwards, 2015; Yüksel, 2004). According to Jackson (1968, p. 10), three factors affect the learnings which are in the scope of hidden curriculum. These factors are (i) crowd, (ii) praise and (iii) power. Learning to live in a classroom means learning to live in the crowd. At school, many things are done together with others. When students are assessed by others (teacher, peers), they learn everything. This means that they learn how they should behave within the society by means of rewards and punishments they get. School is a place where the difference between the strong and the weak can be seen clearly. This is a definition of the strict aspect of inequality between the students and their teacher. Thus, students learn how to react to an authority. Accordingly, hidden curriculum becomes effective in equipping students with such skills as keeping silent, cooperating, continuing to study, being docile, being loyal to their teachers and classmates and being polite. Dreeben (1968) lists four major norms which are transmitted to students in school in the context of hidden curriculum. These norms are independence, achievement, universalism and specificity. According to Yüksel (2004), students learn to take responsibility with the norm of independence, to overcome a failure and reach upper standards with the norm of achievement and the behaviours based on equality of the individual with the norms of universalism and specificity. According to Hafferty \& O'Donnell (2014), the rules, values and norms embedded in the organizational structure of the school and culture that support or confront to the formal curriculum are in the scope of hidden curriculum. 


\section{EVALUATION OF INFORMATION TECHNOLOGIES TEACHERS' IN-CLASS BEHAVIOURS IN THE CONTEXT OF HIDDEN CURRICULUM}

There are some studies which have been conducted to determine the content of the hidden curriculum in related literature. Some theorists have analyzed the hidden curriculum by discussing the factors of socio-economic and cultural differences, social class and gender and by correlating school with political and economical life (Apple, 2004; Lynch, 1989; Skelton, 1997). Besides, some studies have focused on the professional aspect and organizational culture aspect of hidden curriculum. For example, Gair (2003) examines the scope of hidden curriculum in teacher education programs in education faculties under the titles of culture, getting a profession and method while Ahola (2000) categorizes it in terms of higher education under the titles of learning to learn, learning the profession, learning to be a master and learning the rules. Beside these studies in the related literature, there are also a great number of remarkable studies conducted for assigning the dimensions of hidden curriculum in medicine and health education (Bandini et al., 2015; Hafferty, Gaufberg \& O'Donnell, 2015; Haidet \& Stein, 2006). For example, Tsang (2011) states that hidden curriculum in medical education is related to the matters of starting the profession, ethics, specialisation, being a role model and lidership. In their study Mossop, Dennick, Hammond \& Robbe (2013) examines the components of organizational culture presented by Johnson, Scholes \& Whittington (2009) as stories, rituels, symbols, organizational structure, control mechanisms and power structure by adapting them to hidden curriculum in the context of medical education. In this regard, professional and organizational culture may be claimed as an important component of the hidden curriculum.

On the other hand, the sources that have a role in occurance of students' unplanned learnings are also in the scope of hidden curriculum. Accrodingly, the scope of hidden curriculum is shaped around those three main sources (Yüksel, 2004, p. 57): (i) the managerial and organizational means and regulations of the school (such as the rules and architecture of the school and composition of the classrooms). (ii) interactions between the school and the environment (such as social norms and values). (iii) the athmosphere of the classroom (such as student's characteristics and gender and teacher's behaviors and prejudices). Matters related to morality, personality, values education and ethics are also learned in the scope of hidden curriculum as well as the formal curriculum (Çubukçu, 2012; Doğanay \& Sarı, 2004; Yüksel, 2005). According to Tezcan (2005, p. 176), there are a lot of socio-cultural factors that enter the scope of hidden curriculum such as the behaviours, approaches, beliefs and values of teachers and administrators working in the school, the quality of the school atmosphere, the interaction sequence that the school setting offer to the students, unwritten rules in school, routines, discipline and obeyance to the authority.

\section{Teacher Behaviors and Hidden Curriculum}

While trying to help students gain the aimed values, norms and rules through formal curriculum in the classroom, teachers may be effective in occurance of unplanned learning situations which are not stated in the formal curriculum either being aware or not (Karimi, Ashktorab, Mohammadi \& Abedi, 2014; Mosalanejad, Ghobadifar \& Akbarzadeh, 2015; Yüksel, 2005). According to Previna (2011), teachers undertake an intermediary role in implementing the hidden curriculum of the school. The hidden curriculum is influenced by teachers' political, religious and cultural ideologies, preferences and attitudes, prejudices, opinions and expectations about students in learning process, the rules that they set up in class and the personal and professional characteristics that they hold (Yüksel, 2004). During lessons, even teachers' teaching styles related to topics which they internalize or regard as unimportant may change. For instance, a teacher who internalizes the principle of statism will teach it more enthusiastically while a teacher who does not internalize this principle teaches it in a more dull and superficial way (Yüksel 2004). In their study based upon inclass observations, Elitok \& Kesici (2010) observed in the course of Revolution History and Kemalism that the teacher of the course mentioned topics related to Kemalism less, valued the rules too much and embarked upon the traditional structure of Turkish culture and that all these circumstances affected how the lesson was conducted.

Teachers' messages and reactions about morals or ethics are also related to hidden curriculum (Çubukçu, 2012; Mosalanejad, Ghobadifar \& Akbarzadeh, 2015; Yüksel, 2005). In related literature, it is known that teachers display unethical behaviors such as being late 
to class, leaving the class early, discriminating in their relationships with students, sharing their ideological views in the classroom, behaving students in an oppressive way, giving punishments, smoking in places open to students and threatening students with low marks (Elitok-Kesici, 2010; Pelit \& Güçer, 2006). In their study, Altınkurt \& Yllmaz (2011) observed that the most frequently repeated unethical behavior by teachers was that they did not pay enough attention to unsuccessful students. Hence, teachers' such behaviours may lead to occurance of unwanted behaviors in those students. Students' success states, names, genders, social classes, socio-economical conditions and ethnic origins are among factors which are in the scope of hidden curriculum and have influence on the differentiation of teachers' behaviours (Nelsen, 1981; Tezcan, 2005; Yüksel, 2004). Similarly, in the study conducted by Sarı \& Doğanay (2009); it was seen that a teacher working in a school with a high life quality displayed the behaviour of respecting human dignity and equalty more than a teacher working in a school with low life quality.

Different from those studies above, Saldıray \& Doğanay (2017) examined the notion of social gender in depth within the context of hidden curriculum in their study. As a result of the study, they found out that teachers reflected their gender-related stereotypes in their practices in teaching-learning process, those stereotypes varied by teachers' sexes, teachers unwittingly made sexist speeches and students internalized those hidden messages. In their comprehensive study in which they evaluated schools' sensitivity to social gender, EnginDemir et al. (2016) found out that male teachers holded a more traditional viewpoint while female teachers holded a more egalitarian one. On the other hand, teachers' behaviours differ according to students who obey and do not obey the rules. In accoridance with this, it is possible to mention the impact of reward-punismnent mechanism. Students can learn that they will be punished and be exposed to physical and verbal violence when they do not obey the rules and that they will be regarded as beloved students by their teachers when they obey the rules (Adray, 2011). While the students who obey the rules are viewed more successful, more obediant, more docile and better students, the students who do not obey the rules can be labelled as naughty, unsuccessful and bad students. In his study, Tuncel (2008) observed that teachers' behaviours were more influential than their words on students with respect to being a role model and that whatever is told and claimed in the class affected emotional characteristics of students. In addition, what have an important role in occurance of the hidden curriculum are teacher's addressing to students with their names and approaching style, the type, quality and level of the teacher communication with students, and their expectations from students (Lavoie, 2006; Yüksel, 2004). Giroux (2011) underlined the critical role of teacher in conveyance of the values in the socialization process of students in the context of hidden curriculum along with the formal curriculum.

In the event that teachers' expectations contradict with their behaviours, the impact of the hidden curriculum becomes more apparent (Yüksel, 2004). For instance, if a teacher who talks about democracy education including such concepts as equality, freedom and justice in class does not act in accordiance with this approach, then it may be said that there is a teacher-centered understanding where authority, oppression and discrimination dominate and students do not have a voice in the class. Similarly, teachers want students to gain high-level skills such as problem-solving and critical thinking. Even though these characteristics are clearly stated in the formal curriculum, it is seen that the importance is given to activities which make students learn the subjects by heart (Cobanoğlu \& Engin-Demir, 2014; Yüksel, 2004). Accordingly, the significance of teacher behaviours in occurance of the hidden curriculum becomes apparent (Giroux, 2011; Yüksel, 2004).

On the other hand, written symbols, verbal or nonverbal messages, visuals, coursewares, videos and various learning objects that teachers use in lessons may be viewed as a means to establish the function of hidden curriculum (Adams, 2017; Hubbard, 2010). Especially, as the use of technology has become widespread in digital age, the relation of teaching technologies used in lessons to hidden curriculum has started to draw attention of researchers. Accordingly, unplanned learnings may occur in lessons by means of information and communication technologies. In addition, the ethical matters on the use of these technologies are also relevant to hidden curriculum (Adams, 2017). In the studies conducted on this topic, it was seen that teaching technologies and coursewares such as books, works of 


\section{EVALUATION OF INFORMATION TECHNOLOGIES TEACHERS' IN-CLASS BEHAVIOURS IN THE CONTEXT OF HIDDEN CURRICULUM}

art and visual materials may carry inexplicit and hidden messages that include a variety of codes and alghorithms (Adams, 2017; Anderson, 2001; Edwards \& Carmichael, 2012; Edwards, 2015). Therefore, this present study focuses on hidden curriculum in a specific course about information technologies. As a matter of fact, both the evaluation of unintended outputs in technology education and the presentation of a concrete image by examining the hidden curriculum which is, in some way, the invisible part of the iceberg (Marina, 1999) in terms of effectiveness of learning in the context of teacher behaviours can enable making educationally remarkable inferences. Because teachers' reactions may have positive or negative impacts on students in relation to hidden curriculum (Alsubaie, 2015; Cotton, Winter \& Bailey 2013; Hafferty \& Gaufberg, 2017, p. 35). In other words, unintended and unplanned learnings that stem from teacher behaviours may not only contribute positively to the socialization process of an individual and the function of education but also cause the occurance of goals reversing to the formal curriculum by not recognizing the goals of the formal curriulum (Cotton, Winter \& Bailey, 2013; Sönmez, 2008).

When behaviours that teachers display are taken into consideration as a determinant of the hidden curriculum, the significance of not ignoring them in studies of education and efforts of curriculum development gets more apparent. Hafferty \& Gaufberg (2017, p. 35) state that the negative outputs of the hidden curriculum may not be completely surpressed but may be taken under control administratively within the process. In this respect, what the learnings that occur beyond the formal curriculum are and how and when they are taught must be identified in order to take measures against unintended learning situations (Yüksel, 2004). Studies on hidden curriculum are observed to be in restricted numbers (Adams, 2017; Edwards, 2015) while studies on information technologies in the scope of formal curriculum are met frequently (Çengel, 2007; Dursun \& Saraçoğlu, 2016; Karakuş, Coşğun \& Lal, 2015; Uzgur \& Aykaç, 2016). In these studies, the focus has been on the instrumental function of technology within the context of hidden curriculum rather than course-centered approaches. In light of these explanations, it is aimed to evalute the in-class behaviours and the factors which are effective in occurance of these behaviours in the context of hidden curriculum on the basis of the opinions of information technologies teachers.

\section{Method}

It is seen acceptable to use the qualitative research methods beside relatively using quantitative research methods for this study since detecting the messages and behaviours repeated within the natural setting and analyzing the data deeply are recommended in the studies of hidden curriculum (Dickerson, 2007; Yüksel, 2004). In this way, remarkable messages, incidents and experiences can be detected within the scope of the researched topic related to the hidden curriculum. Therefore, from the qualitative research methods, the phenomonology research design which puts emphasis on participants' experiences was used in this study. In phenomonological design, the phenomenons that we encounter in daily life as incidents, experiences, perceptions, situations and tendencies of which we are aware but not have an in-depth understanding are examined (Y ldırım \& Şimşek, 2016). In this design, the meanings set by the individuals or groups as a result of their experiences with this phenomenon are investigated to reveal the phenomenon that the study focuses on (Creswell, 2012). The phenomenon discussed in this study is 'the behaviours' that information technologies teachers display during lessons in the context of the hidden curriculum. To reveal this phenomenon, teachers' opinions about their own behaviours are examined in detail. Significantly, teacher behaviours can be observed directly within the classroom setting or be revealed based on student opinions. However, this present study focuses on teacher opinions since identification of the latent and contradictory factors that lie behind their behaviors by evaluating teachers' own viewpoints and inner worlds in the context of hidden curriculum are also thought to be important.

\section{Study Sample}

As there is a detailed and in depth examination in studies conducted in phenomenology design, a great many people should not be involved in these study (Y 1ldirım \& Şimşek, 2016). Therefore, small sample may produce better results than a study carried out on a large sample (Karasar, 2012). In selection of the study sample, from the purposeful 
nonprobablistic sampling methods, the criterion and maximum diversity samplings were used. In accordance with criterion sampling method, the criteria taken into consideration for selection of the participant teachers in this study are (i) being a graduate of Computer and Instructional Technologies Teaching Department of Education Faculty or Electronics and Computer Education Department of Technical Education Faculty, (ii) being teaching at a secondary school and (iii) attending the study voluntarily and willingly. In maximum diversity sampling, to ensure diversity, it is aimed to diagnose the types of similarities and commonalities among various cases instead of making a generalization for the population. In this study, in compliance with the maximum diversity sampling, care was taken to select the teachers who were working in schools with different socio-economic levels (lower, middle and high level) identified by the National Education Directorate of the city where the study was carried out. Because the hidden curricula of the schools in different socio-economic levels are prominently different (Saldıray \& Doğanay, 2017; Sarı \& Doğanay, 2009). In accordiance with this, the study sample consists of 15 information technologies teachers who work in secondary schools in a central district of a city located in the West Blacksea Region in Turkey. $11(73.33 \%)$ of the teachers participating in the study were male, 4 of the participants $(26.67 \%)$ were female and their avarage age was $30.46(\mathrm{SS}=2.74)$. Only 2 of the participant teachers had a master degree. Years of seniority varied from 3 to 13 years. On the other hand, 5 of the teachers were from secondary schools with a low socio-economic level while the other 5 and the rest 5 were respectively from the ones with middle and high socioeconomic levels.

\section{Data Collection}

For collection of the data, semi-constructed interview forms prepared for teachers were used in this study. Semi-constructed interviews offer more flexibility to researchers than structured interviews; they allow to reach more details and explanations through the questions at the end. Making interviews with teachers in the present study is important in terms of also revealing open, latent or contradictory elements that lie behind their behaviours in the context of hidden curriculum. Therefore, in phenomonological studies, interview technique is frequently preferred by researchers as it requires using interaction, flexibility and probing through probes features that it offers to researchers in order to reveal the experiences and meanings with respect to the phenomenons (Y lldirım \& Şimşek, 2016). According to Frankel \& Devers (2000), the intentions, attitudes, perspectives, interpretations and perceptions of the participants are tried to be elicited in detail through interview technique.

Before preparing the semi-structured interview forms, the related body of literature with regard to revealing the hidden curriculum was examined. Since teacher behaviors are evaluated within the context of the classroom climate aspect of the hidden curriculum (Çengel, 2013; Yüksel, 2004), in the interview form, there are questions related to the circumstances about the hidden curriculum such as teachers' states of being democratic in the class, discriminating between students and being biased; their messages about social, cultural, ideological values and school identity, their state of being a role-model, and commucitaion with students. In the preparation of interview questions, opinions about scope and appearance validity of the form were obtained from a total of 8 faculty members 4 of whom have at least Ph. D. degree in Educational Programs and Teaching, the other 2 in Assessment and Evaluation and the rest 2 in Computer and Teaching Technologies Education. In addition, the suitability of the questions in terms of language was checked by two linguists and pilot interviews were made with two information technologies teachers out of the study group for clarity. The necessary corrections were made and the final form was given to the interview form consisting of eight main questions.

The interview form consists of two parts. In the first part, questions about participants' demographic information (such as gender, school name, seniority, graduation, e-mail) are included. In this part, there is also a section including general explanatory information (date, time, etc.) about the interview. In the second part, interview questions are included. Interview questions are designed to get detailed information from the participants, not to say yes or no. Some of the interview questions in this part are as follows: (i) How is your 


\section{EVALUATION OF INFORMATION TECHNOLOGIES TEACHERS' IN-CLASS BEHAVIOURS IN THE CONTEXT OF HIDDEN CURRICULUM}

teaching style (authoritarian, collaborative, democratic, etc.)? Which methods and techniques do you use predominantly in lessons? How is your behaving and approaching style to your students? (ii) How do the individual differences (such as socio-economic status, achievement status, gender) of students affect your behaviors in the class (such as methods, communication)? (iii) Which of your personal opinions, thoughts and values do you reflect in your classes?

Importantly, with respect to the evaluation of teacher behaviors in detail and the identification of the elements that motivate them to do these behaviors participants were asked to answer plenty of questions at the end of the form such as "Can you give an example?", "Can you criticize yourself in this matter? ", "What are the reasons for your such directions?", "Can you give an example to the slang words you use? ", "How do these problems affect your expectations?", "Do you use licenced softwares on your own computer?", "What it your reason for displaying this behavior?", and so on. Permission was obtained from the relevant Directorate of National Education in order to carry on the research and interviews. Before the interview, the appropriate place and time were planned for the participants and interviews were conducted face to face in the laboratories of information technologies or teachers' rooms. During the interview, an audio recorder was used with the permission of the participants, and notes were taken by the researcher. To ensure that the voice recordings are clear and understandable a professional device was used during interviews. The participants were given the confidence that their personal information would be kept hidden and that the interview data would not be used for any purpose other than the scope of the research. Face-to-face interviews lasted approximately 30 to 90 minutes.

\section{Data Analys is}

The data obtained from the interviews in the study were analyzed by both descriptive and content analysis methods. In descriptive analysis method, the data are summarized and interpreted according to the previously determined themes. These themes can also be arranged according to the research questions or the questions used during the interview (Ylldırım \& Şimşek, 2016). In this respect, some interview questions in the form were prepared in accordiance with the scope of the hidden curriculum in the context of the related literature. For example; the question on the interview form "What are the activities that you implement for students to adopt the identity of the school?" was established in relation to the pre-determined "school culture" theme. In content analysis, the main goal is to understand the explanatory concepts about the data and the relationships between them. This analysis allows for the emergence of themes that were not specified beforehand. In addition, the data summarized and interpreted in descriptive analysis can be passed through a more detailed process by content analysis method. (Yıldırım \& Şimşek, 2016). Thus, concepts and themes which can not be diagnosed with descriptive analysis can be discovered as a result of this analysis. Therefore, messages which are hidden within the data can be revealed in this way.

In the first phase of the data analysis, the audio recordings and the notes taken during the interviews were converted to a 142-pages script in the computer environment (via MS Office program) by giving a code number for each teacher such as T1, T2, T3 and so on in order not to decipher their identities. While this process was being conducted, the statements of the participants were quoted directly without altering any expressions. The texts were re read several times and their equivalents were conceptually coded to constitute meaningful wholes. After this phase, similar and interrelated codes were combined to obtain themes. In the last phase, the findings were explained and reported in detail and interpreted in the light of the related literature.

\section{Validity and Reliability}

In assurance of the validity and reliability of the study, attention was paid to ensure the characteristics of credibility, transferability, consistency and verifiability (Yildırım \& Şimşek, 2016). In the efforts to increase credibility of the study, long-term interviews were tried to be done by creating an environment of deep trust to obtain more sincere answers from the participants. Since there might be some periodical changes in the collected data, 
interviews more than one were made with some teachers. Findings were directly supported by quotations from the participants' statements. In order to ensure the transferability of the study, the research process (research model, data collection tools, data analysis, etc.) were described in detail and systematically. In addition, from purposeful sampling methods, criterion and maximum diversity sampling methods were used in the selection of the study sample. With regard to verifiability, the audio recordings, raw data and encodings in the investigation are being kept by the researcher to allow for the review by those concerned. Besides, the results of the study and the validity of the raw data were examined by two expert researchers, and the accuracy of the audio recordings which were converted to scripts was verified bye-mailing to the participant in accordance with the research ethics. Coding in the research was carried out by other two researchers together with the researcher. In order to ensure the reliability of the study in this sense, the coherence value (Cohen's Cappa coefficient) was calculated to decide whether the study provided a consensus among the coders or not. The Cohen kappa value $(\mathrm{k})$ shows a poor level of compliance when it is between .21 and .40, a moderate level when it is between .41 and .60 , an adequate level when it is between .61 and .80, and a good level of compliance when it is between .81 and 1.00 (Altman, 1991). In the present study, the value of $\mathrm{k}$ was found to be .84 , which indicates that there is a very good level of consensus among coders.

\title{
Researcher's Role
}

Although the role of the researcher in qualitative research differs from quantitative research, researcher is the person who directly observes the study sample in its natural environment, inteviews them and experiences the same situations of the study sample when needed (Yıldırım \& Şimşek, 2016). This means that the researcher himself/herself also functions as a data collection tool. In this research, the researcher took responsibility for planning, conducting and evaluating the study correctly and reliably. In the days and hours previously scheduled with the participating teachers, they conducted interviews without violating the course order. Throughout the interviews, an ethical approach was adopted and the situations that might adversely affect the data collection process were avoided. The researcher analyzed and reported the data obtained from the interviews.

\section{Findings}

After the analysis of the research data, teacher behaviours in the context of the hidden curriculum were divided to seven sub-themes, namely "power and authority", "prejudices and discrimination", "narratives", "communication", "role model", "getting a job" and "school culture".

Power and authority: This sub-theme emphasizes that the teacher views himself/herself as an authority in lessons and adopts a teacher-centered approach. The student's obediance and respect to the authority and the press, and the emergence of the sense of fear against the domineering powers are also related to the sub-theme of power and authority. As a result of the interviews, most of the teachers stated that they wanted the students to be respectful, $(n=14)$, be docile $(n=12)$ and to obey the rules $(n=9)$ verbally. The following quote is a teacher's statements related to these findings:

\begin{abstract}
"The important thing I want to see in a student is respect, once respect is ensured, the rest comes. I'm talking about the fact that student should respect their teachers. The fact that teachers are not respected is, now, one of the most important shortcomings of our day. As a teacher, you cannot scare the child as teacher's many rights have been reduced. When you say something, you are found guilty... When a teacher enters the classroom, he/she has an authority. The pupils have to do what the teacher says and the teachermust have some authority. Otherwise, the student starts to ignore and disrespect the teacher after a certain time. So, sometimes it's time to take over a little bit of authority. As you approach the students to some extent and have a good teacher mode in the class, they use your this weak point, abuse your emotions and try to make you do what they want." (T1)
\end{abstract}

The teacher coded with Ö13 explains his/her opinion about the fact that students can learn not to be docile, not to obey the rules and not to listen to the teacher and the lesson in accordiance with their interests since the teacher is not authoritative in the class as follows: 


\title{
40 EVALUATION OF INFORMATION TECHNOLOGIES TEACHERS' IN-CLASS BEHAVIOURS IN THE CONTEXT OF HIDDEN CURRICULUM
}

\begin{abstract}
"Because the lessons are in the laboratory, students are more engaged with computers there. the design of a computer laboratory is in the form of horseshoe. The students have to turn their bacs to me. Because of this, the students get sometimes disconnected with the teacher and talk to the friend, and they are distracted by the computer. There are two or three studens on each computer. Most of the time there is a buzzing noise in the class. I do not like this at all, students can not listen to what I tell. So I often have to warn them about looking at me and turning to my side... I want them to do what I say... I have my own rules... The students will not do anything on the computer, they will not talk to other students, they will only listen to me. Otherwise, if they are allowed to be free, some of them will play games on the computer and the others will surf the net." (T13)
\end{abstract}

It was seen that some of the teachers have set their own rules in the laboratory. In this respect, some teachers stated that they display behaviors such as resigning computers to the students $(n=3)$, punishing the students that give any damages to the computers $(n=2)$, keeping watch in the laboratories during breaks $(n=1)$. Taking into account the teacher's dominance, students may be subject to a severe reaction from their teachers if they do not obey these rules and receive punishment if they do not listen to the lesson. As reference to these findings, the statements of the teachers are as follows:

"I set the lab rules. I debitted each computer to whoever was sitting at the desk in each class. I wrote their names. When anything happens to the table, the computer or the mouse, I ask that student to account for it or every day a keyboard or a mouse breaks down. I can not cope with it. In breaks, a student from the previous class is on duty in turns every week. By this way, the sense of responsibility develops in students." (T13)

"Sometimes I get annoyed with and shout at those who do not listen to me, romp in their desks and damage the computers. As punishment, I do not allow them to use the computer in that lesson. As they know this, they keep silent of necessity... I have a firm personality, they become silent right after I shout at them. What else can be done? Since the course does not have a marking worth, the students feel secure. It's like a game lesson for them... they often ask me when I will let them play games on the computer or when I will set them free. If they are allowed to play games for a few times, they get used to it and want it all the time. They even praise you saying "you are a very good teacher, we love you a lot, we wish we had more classe and so on." (T8)

Rather than a democratic environment, teacher's applying his/her own rules about both the class system and use of the computers and resorting to verbal violence can be described as an authoritarian behaviour. Students can learn that they may encounter various sanctions if they do not obey the rules set by the teacher. On the other hand, the system of the computer laboratory, the impact of technology on students, and the lack of marking value of the course lead to the emergence of learnings such as behaving comfortably and not taking the teacher's behaviours seriously. 9 of the teachers expressed that they conducted the lesson relatively away from student-centered understanding. For example, explanations from two teachers are as follows:

"In order to catch up with the curriculum, I teach the lesson and let the students practice it. Sometimes, I do have to use the break because the lesson duration is very short... I usually make a presentation in the lesson and then the children apply the things that I have just told on their computers as long as they can." (T6)

"As a method, I can say that I do not use much the active learning methods or such interesting methods that appeal to children. I mostly teach via projector and then the students do what I have told them on their computers... They obey the rules, and now that they have learned my style. They have to obey. After all, the teacher must certainly have an authority." (T15)

Although theoretically, the curriculum of the course adopt a constructivist approach that put the student in the center, in practice, it appears that teachers prefer methods and techniques that do not put the student in the center. The fact that the teacher-centered approach is dominant requires the students to comply with their teacher's beliefs and thoughts, much more than their own wishes and needs. Students are not able to use creativity and curiosity while learning to memorize knowledge in these settings and to be dependant on outer sources and away from productivity. In relation to the sub-theme of "power and 
authority", some teachers $(n=5)$ reported that they could not threaten students with exam grades and this weakened their authorities. This situation can cause students to feel comfortable and not to care about the lesson. As an example, the teacher coded with T2 expressed his/her opinion as follows:

\begin{abstract}
"Our lesson takes place one hour a week and have no grading value. There is a curriculum that we have to apply ultimately, and the child is miles away from the class because he knows that there is no grading value of the course. The child is irrelevant as he/she knows that there is no necessity to learn the parts that the exam will cover. This upsets me and I can not make the students mind me. But if there were a valid mark, you can intimidate the student and thus they show interest in the lesson... The student wants to have high marks. When the student behaves pertly or confronts to you, you can lower the grades or give a minus and have a power of sanction. Only then, the student makes what I say."
\end{abstract}

Prejudices and discrimination: This sub-theme is related to the behaviours that teachers exhibit in a biased and discriminatory manner according to certain characteristics of the students. Teachers underlined that they mostly favoured the students who were successful $(n=11)$, predisposed to information technology $(n=9)$ and obedient $(n=9)$. As a reference, some teacher opinions are given below.

\begin{abstract}
"I teach in different ways according to the classes. I do not know whether this means discriminating. To give an example, in this school 6-C is a successful class full with selected students. I have lesson with this class on Friday afternoon. I wish friday came quickly and all my classes were like that. I like the class 6-C very much. The students in this class not only do whatever I tell but also are very hardworking. They are all wonderful students. The lesson in this class is very enjoyable, this relieves me from the tiredness of the whole week... Lessons are more productive, it is fun to teach there... Of course you are more soft-mannered in this class, I do not get very angry. I also teach the class 6-F, and I teach them on Tuesdays. They are so spoiled that I drag my feet while going to the lab. Everyone is biased about this class. Do you believe that an hour lesson seems like a whole day to me? Other teachers complain too. Everyone fulminates against 6-F class." (T11)

"I am more closely interested in students who are predisposed to technology, software and hardware. It is a truth that I care for them more closely. I can call this positive discrimination. Maybe because of this field, we have interests in common. Children who are open to development are more interested in lessons, they are constantly asking about anything in breaks, they show themselves." (T7)
\end{abstract}

In addition, 4 of the participants made explanations that teacher behaviours differentiate according to the life quality of the school and the socio-economic status of the students. Examples of some participants' opinions in this direction are as follows:

"The parental profile of the school in which I work is high. I the school, Students' parents are mostly doctors, teachers or businessmen Therefore, there is a parental pressure on the teachers. I feel this pressure on me, as well. Especially mothers are always in the school. A teacher, my friend, shouted rightly at the student and the student immediately complained. So, my friend went through an investigation. Of course you get demoralized when you see these incidents. Neither the school administration nor the National Education Directorate is on your side. As this is the case, you have to behave the students more carefully." (T13)

"You can teach something to those who are willing to learn. Efforts for others seem to be in vain, because there is no progress in the child even if you care about her/him at the beginning. The child has family and financial problems. He/she is thinking about other things during lesson." (T12)

"I used to work in a school of high quality before. This school, in which I work, with is a suburb school, the economic situation of the families is not good, most of them work at minimum wage. So, it seems as if they do not have many expectations. As such, you do not pay attention to students in lessons. I do not bother much, as it will be in vain. Even the simplest thing is interesting to students. Some of them do not have a computer at home... I observed the lack of self-confidence in children. I have such a student who is afraid of breaking the keyboard or the mouse in the lab." (T5) 


\title{
42 EVALUATION OF INFORMATION TECHNOLOGIES TEACHERS' IN-CLASS BEHAVIOURS IN THE CONTEXT OF HIDDEN CURRICULUM
}

From these explanations, it is understood that teachers care about students in schools with a high life quality and socio-economic level much more whereas they conduct the lessons more superficially and in a teacher centered manner in schools with a lower socioeconomic level. In addition, teachers' behaviors are shaped by the expectations of the administration and the parents. Moreover, some of the teachers reported their opinions on the fact that they favoured male students $(\mathrm{n}=2)$, and the students who were engaged in sports and art $(n=1)$. Therefore, students can develop learnings such as being behaved warmer by teachers or receiving higher grades when they are successful on a field. Statements of some participants that support these findings are as follows:

"This school is a good school. After all, everyone has an expectation. Parents want their children to get a good education. Our director is constantly telling us to do projects and different activities. He loves to make a name with bombastic things. I constantly direct children to projects and competitions related to information technologies and support them." (T7)

"Some of the students are engaged in sports and art. These are priorities for me. Sometimes I assign performance works to these students. I give more points to them. You become more sincere towards them. After all, they have talents. For example I have a naughty student in the class, but he/she plays football very well. He won prizes, too. Naturally, I behave this student in a different way." (T9)

Narratives: This sub-theme is related to teachers' unplanned statements and reactions to ethical and ideological issues as well as to the social and historical values. The"narratives" theme was discussed in two dimensions as "social and moral" and "ideological". Based on the opinions of the teachers, it was identified that they conveyed messages and made narratives mainly about the "social and moral" dimension. In this direction they emphasized that they told about their and others' life stories and experiences, had the students watch short videos and movies, warned and directed them to cultural events. Some teachers' explanations in this regard are as follows:

\begin{abstract}
"A young generation who is getting more and more alienated and taking Europe as an example is coming. I warn about our culture from time to time... I say that we should kiss the elders' hands at the feast, because this is almost forgotten. We have to eat together at the meals. Because those things are what I have experienced and what I consider important... I often recommend films with good educational content. If I could, I would have the students watch such films every lesson, but the duration of the lesson is very limited. But I get them watch short videos There are impressive and pleasing short videos about humanity... Children love animation movies at these ages. Actually, I wish there would be animated movies or videos that tell us our values in a funny and sympathetic way." (T12)

"Our ancestors have fought in these lands. We owe to them a lot. So, I tell them to love the country and the nation and how valuable our martyrs and veterans are... Of course, also social sciences teachers and others are certainly teaching all these. But these are the subjects that all teachers should talk about from time to time. Besides, we have social values. For example, I tell that there used to be a sense of sharing and what happened in the Ottoman period. I tell them that we are so compassionate and that our land has grown so much because we were not racist and discriminatory. We are talking about a nation that opens its doors to everyone." (T7)
\end{abstract}

"Teaching is not only teaching your lesson. Our most important function is to make students feel that education is value-driven. I like talking about life in the class. I also tell about the lives of people who have left a mark on our lives. The closest example is our godfather Izzet Baysal, who is the symbol of goodness. Izzet Baysal is the most important symbol and value of Bolu. He had his school built. I wish our students would grow up and be like these people. I share the meaningful words of these valuable people. These people are also a value for us." (T2)

It is remarkable that giving examples from lives of well-known people and of others and using visual materials that create awareness are more effective than direct teaching in adoption of moral and societal values by students. The T3 coded teacher pointed out that $\mathrm{s} / \mathrm{he}$ 
directed the students to a charity campaign organized by him and as a result this campaign attracted the attention of the students and created awareness. Contrary to this view, the following expressions obtained from the teacher with the code T9 are remarkable:

\begin{abstract}
"Giving examples directly from my life about topics such as goodness, benevolence and justice is a little ineffective. Saying 'I have done a favour, I helped someone.' may lead students to make different inferences. So sharing something from the lives of important people about that topic can leave an impact. For example, while talking about the concept of justice, one of Hz. Ömer's sayings and a short film or video about benevolence, goodness and respect in our culture, perhaps, are more impressive. Somewhat emotional things can be more effective in assimilation of these concepts by children... I direct them to activities inside or outside the school that promote our culture and I also share it on our school website."
\end{abstract}

In relation to the "ideological" dimension, it was found that the teachers made religious $(\mathrm{n}=5)$ and political $(\mathrm{n}=2)$ speeches. In this direction, it was observed that the teachers guided the students either being aware or not according to their own ideological thoughts. As an example, some statements from the participants are as follows:

\begin{abstract}
"I never open a political topic... But -because I am sensitive to these matters-I tell, talk and give examples in order that students can be a religious person. During lessons I sometimes tell that Allah has created these things, and that our religion instructs us not to do evil and that we must be good people... A faithful student who knows his/her religion will not lie, s/he will be honest." (T5)

"I congratulate the days of the students at the beginning of the lesson on Qandil and religious festivals. I make a short speech. I try to imbue them with the need for unity and being together. Even if there are students who do not speak to each other in class, I want them make peace." (T12)

"Sometimes I talk about the state of the country and the future. Even if I do not go too far into the administrative issues, they are mentioned incidently. I do not give a name directly by saying s/he did so. But sometimes I talk about the negative incidents on the agenda. Depending on the way you talk, you may sometimes need to tell these to the students so that they can question the incidents and take lessons from them." (T3)
\end{abstract}

The teacher coded with T13, ethically, bases the students' not using the nasty websites, not hacking and not tending to violence to religious beliefs. This may be effective in improving unplanned learnings in students. Teachers' statements in this direction are as follows:

"I think, violent games and movies are troubled. They change the personality of the student... I explained it is not appropriate to steal other people's information in virtual environment as much as the real theft. First of all, I told them that it was not acceptable in our religion. I think, the religions actually say the same things as these moral situations... The same thing is true especially in the case of sexual-content sites, they can not enter those inappropriate websites at school but they can enter such websites at home..." (T13)

Communication: This sub-theme emphasizes the unplanned activities that emerge from verbal and non-verbal reactions and interrelations of the teacher and the students in order to understand each other. On the basis of the teacher opinions, this theme is examined in two dimensions as "positive communication" and "negative communication". Teachers' opinions were found to be mainly related to the dimension of "positive communication". In this direction, teachers expressed that they mostly listened to student requests $(n=8)$, and behaved cheerfully $(n=7)$ and sincere $(n=7)$. In addition, some of the teachers also pointed out that they empathized with students $(n=5)$, addressed to students with their names $(n=4)$, approached them like their friends $(n=3)$, give importance to body language $(n=2)$ and made eye contact $(n=1)$. Teacher views that support these findings are as follows:

"I usually have a smiling face. This is the way I approach my students. I usually listen to their problems and try to find a solution. We need to be friends with students. Ifeel they love me, too... Especially in some classes I feel it more. It's different when emotions are mutual. I think this job absolutely has an emotional side... A student should love the teacher in order to love the lesson." (T1) 


\title{
44 EVALUATION OF INFORMATION TECHNOLOGIES TEACHERS' IN-CLASS BEHAVIOURS IN THE CONTEXT OF HIDDEN CURRICULUM
}

At this dimension, it appears that the teachers take a positive approach towards the students. As a result, students may feel that they are valued and minded. On the contrary, the negative communication established with the student can lead them to be frightened by the teacher, to see themselves as worthless, not to be able to express their feelings and thoughts freely. As a reference to these explanations, the opinions of the some teachers are as follows:

\begin{abstract}
"If you do not communicate positively with and care for a student, the student will not respect you and s/he will ignore your views... Teachers should not be too harsh to students. It is best to have a feeling for them while approaching..." (T5)

"In a secondary school age when children step in adolescence, children can be a little bit emotional. We need approach them in a careful and empathic way in this phase. Otherwise you cannot find a solution by shouting and scolding. They do not like you in this way and if they do not like, you they will not like the course, too." (T13)
\end{abstract}

In terms of the dimension of "negative communication", teachers mostly expressed that they behaved the students harshly and communicated with them by shouting. These situations may lead the students to develop negative attitudes towards the teacher. However, some of the teachers also reported that they acted in insulting $(n=5)$ and disregarding $(n=3)$ manners towards the students. The participant statements supporting these findings are as follows:

"Teachers should not indulge students. It is best to keep a distance between you and the students. Otherwise, it is hard to cope with them. If they find out your slightest weakness, they try to make you do whatever they want right away. You need to show a harsh mood. The IT lab is not like the class, it is both small and crowded. There is a lot of noise and chaos... If you let them be free, they want to play computer games all the time. They will surf on the internet unnecessarily. I know every one of them is a computer engineer when asked, but they do not use it consciously... Sometimes I do not let them use computers in lessons. I make explanations and inform about the mistakes they make while using information technologies." (T9)

"I don't care about spoiled students. I apply the technique of ignoring when those ask anything. Obviously, those students do not make any efforts or do nothing. They come to class aimlessly. They do not do the homework that I give or even if they do homework, they do it either carelessly or reluctantly. I don't take such students very seriously. Because, you know what you're doing is in vain." (T13)

Role model: This sub-theme is related to the teacher's behaviors about the ethical, moral, and social values that set an example for students. In this sense, most of the teachers $(n=12)$ criticized themselves that they set more negative models for the students. Specifically, 7 of the teachers explained that they set bad examples mostly because of the fact that they did not comply with the principles of information ethics. As a reference to this finding, some teachers' opinions are as follows:

\footnotetext{
"You may talk about information ethics in lessons, but this topic is a bit critical. As a teacher, for example, you tell that software, movies, games and etc. have a copyright... But, we obtain many unlicensed and illegal programs by theft -for example by crackingin order not to pay money on the internet. I do that, too. Actually the circumstances force us to do so. There is already a system for doing this. You think, 'Why shall I pay money?'... But even if I know that it is not ethical, I still tell the children that they may find a game cracker on that website. It sounds like I did a favour for them. But it's not ethical." (T4)
}

Even though I do not wish to do so, there may happen differences between what I say in the class and what I apply in my own life in this regard. It is difficult to prevent piracy. Whatever we say about downloading games and movies free on the net, I am not sure about how effective my words are on students as I do the same thing. (T4)

\footnotetext{
"I was showing the students a video about computer crimes and ethics. Then, while I was talking to the class, I told them to use the original Office programs as an example. One of the children said, "Teacher, people around me never use the original one, how shall we pay for every program? Do you use the originial?" Sometimes, I also do not use original software. Therefore, you hem and haw. Of course, even if I say that the unlicensed software they download may have a virus inside, it is difficult to convince the
} 
students on a matter that you do not approve... As I did not use the original software, I closed the topic immediately." (T2)

Verbal or non-verbal behaviors of teachers in the class can be a negative example when they are different from their practices in real life, which can lead to the emergence of unwanted learning situations. Thus, it can be said that the behaviors exhibited in daily life and in the class are inconsistent and adverse. Eight of the teachers expressed supportive opinions in this sense, and some of their explanations are as follows:

"I smoke and I tell the students that they should not smoke. Of course, you can not fool kids, we're deceiving ourselves. Of course, I do not know how effective it is... They also see me smoking outside of the school in breaktimes. I know I am a negative example." (T6)

"As a lady, I like to be well-cared. Sometimes I can exaggerate the makeup. You forbid students to have make up at school. You warn in the class or even get angry. But female students can see your make up, too. Even once, my student asked me something about makeup... No matter how much you ban or say that it is not suitable for their age and that they seem ugly with it, they try to take you as a model." (T4)

"I especially warn them to use our language more precisely and correctly in social networks and the virtual environment. I give information about the accurate usage of some incorrect expressions... There is a tendency to alienation in children too much... Unfortunately, the problem is that I use foreign words in social networks or messages. I am not careful about this, either. This is the truth. You tell the students "you should say or write in this way, you should use our Turkish accurately in your correspondences for example on Facebook. But you continue to do the wrong thing yourself. I am against westernization, actually I am uncomfortable with it, but we are also included as teachers in this. Unfortunately, I can be a wrong model. I also sometimes use a little bit slang in my comments due to sincerity. It is also possible that I misuse the language and therefore students may take these wrong usages as an example. Everyone may have faults. In real life, you can be different from school life." (T14)

As a computer teacher, I am crazy about playing computer games... I play also games containing violence or games that are unnecessary to me at all... I tell the stduents not play them during lessons. I do not know if it is because I am a computer teacher or not, some students come and ask me questions about a game. I tell them what to do or the shortcuts. (T5)

However, some teachers stated that they could be a negative model for students because of their behaviours of late coming $(n=3)$, being offensive $(n=2)$, not using Turkish well $(n=1)$ and not being social and cultural $(n=1)$. As an example of these findings, the following teacher views are shown below:

"Teachers of information technologies in the school generally do technical works, too. There were times when I was unintentionally late for classes. The manager wants something, the teachers may have a problem. You have to do it as a formatter teacher. Coming late to lesson may also affect students. They may think that they can also come to class late. So, what can you do if the student also comes late for the lesson? They may misunderstand each time... You can not set many rules so that students shoul not arrive late. Surely, students must be punctual, they should come to class on time. But I cannot get annoyed with a late-comer student because I also do it myself compulsorily." (T8)

"I usually have an angry and harsh mood. Some guys say to me "Teacher, you look like Polat Alemdar". There are people who say that I am charismatic. I think, I have a style like that especially while talking. I hope they do not take me as a model in this mood... Sometimes, I can talk in a firm way to the class, I can break their hearts. A cold air settles in the classroom... If I need to criticise myself, I am unfortunately not very sociable. Students love different and talented teachers and they approach them differently. Unfortunately, this case is the same for computer teachers, too." (T13)

Most of the teachers in this study $(n=12)$ stated that some of the features they had might be negative examples for the students, while others $(n=5)$ explained that they could be positive examples.

"For a student, to take the teacher as a model is only possible with the teacher's real 


\title{
46 EVALUATION OF INFORMATION TECHNOLOGIES TEACHERS' IN-CLASS BEHAVIOURS IN THE CONTEXT OF HIDDEN CURRICULUM
}

\begin{abstract}
and sincere behaviours. The student feels it when the teacher is not sincere or try to make something that he did not do seem as if he did it. The teacher's behaviours in real life reveal such unsincere situations. If a student sees a teacher smoking outside the school, s/he may take this behaviour as an example. If the student hears you using slang, s/he may use slang too... So, the student should trust his/her teacher. If students are involved in a dilemma about their teacher, their trust will be broken and this will damage their relationship with the teacher. On the contrary, if the student sees that you are doing something good such as helping someone, s/he may take your this feature as an example." (T5)
\end{abstract}

It can be said that the student takes the teacher as a role-model according to the sincerity and reality of the teacher's in exhibiting behaviours. At this point, it is important for the students to feel the behavior of the teacher and to connect with it. Some competencies that teachers have may be effective in students' manners of approaching. Some positive teacher opinions are as follows:

\begin{abstract}
"I give examples from my own life. Of course, I expect them to take my good features as examples. Students see their teachers and friends at school much more than their families. In order to be a good example to them, it is necessary to speak in the same way with them. We need to establish a sincere relationship with them. We need to have a close but a little distant relationship... You can be the idol of the child... The most important thing here is that you should improve yourself first. The teacher, who has developed himself in the field and social activities, draws the attention of the student. S/he admires you later... Right at that moment, you can contribute to the student in the sense of human values and moral values." (T3)

"The teacher must be excellent. We all have weaknesses. The student takes good, creative and different teachers as a model... We all have the following thought. "Wow, what kind of teacher is s/he? S/he has an ability or knowledge in relation to every subject". I am trying to improve myself in every way. I'm trying to open up my horizon so that I can open up the horizons of my students. Of course, academic knowledge is accomplished to a certain extent. The primary aim of education is to teach them goodness, values and morality. But, no matter how much you tell them to be honest, you can not achieve this only with words. Once, the student will see the example in teacher. As I like reading books, I note down the interesting examples from books and tell them to children in class... I bring visual samples and interesting incidents from technology magazines to the class... Apart from our course, the student can interpret this as the teacher's reading a lot of books... We can arrange aid campaigns... If we lead these campaings well, we can be good examples in every subject." (T13)
\end{abstract}

Some of the teachers $(n=3)$ stated that they displayed behaviours to adopt the culture and values outside the school, and in the lessons they shared these experiences with the students and tried to be a good model of the human being. As a reference to this finding, the statements from two teachers are as follows:

\begin{abstract}
"I explain the interesting events that I have experienced about the subjective use of our language in the class. Our culture is getting corrupted, we always use the examples of foreigners... To exemplify anything, I give examples from our history and past events. I share my reactions with the students so that they they take a stand towards the values we have been losing day by day... Especially I expect them not to ignore situations against our national values in social networks related to my course and to share our history and what we have forgotten... Yes, sometimes I convey messages through my shares." (T11)
\end{abstract}

"There are a lot of things I do not know about my history. I cannot adopt our values one hundred percent. I am trying to raise awareness of them to a certain extent. How much effective can I be only with things- the incidents I share and behaviours I display- that I occasionally mention in one-hour lesson? I think it's even a success to raise awareness about something like this." (T3)

Getting a profession: This sub-theme emphasizes the unintended messages of teachers related to praising, deteriorating and guiding his/her own field, teaching profession and other professions. Most of the teachers $(n=8)$ gave the messages mostly about the economic contribution of the field of information technologies. On the other hand, some teachers $(n=7)$ 
reported that they directed their students to professions related to their field, while others $(n=3)$ pointed out that the teaching profession was worthless. Examples for participant opinions related to these findings are as follows:

"Knowing computers is important for hiring an individual, and if they use information technologies after they start working, their work becomes even easier. In professional sense, I am trying to improve myself on this issue for future and so I praise my field." (T8)

"Because of my branch, I direct my students to computer related professions. Computerrelated professions are promising professions. There are many side branches of computer field. No one will stay jobless in this field. If someone is a good software developer, then he/she can make his/her own money everywhere as long as he/she improves him/herself. If I knew then what I know now, I would improve myself on software. It is promising. We use a computer-based thing everywhere in life... The richest people in the world are the ones who deal with the information sector... I share the inspirational stories of important people like Bill Gates and Steve Jobs." (T5)

"I advise this field only if the student will be a computer engineer as our job is worthless. At school, your have to do all the work about computer. You can not do your teaching profession. It has become worthless, everyone understands from the computer... You are not even a teacher. For example, I direct them to the health sector... I direct them to professions that they can find jobs and earn money." (T4)

It can be said that the teachers guided the students in professional sense according to the economical state and emphasized the importance of the field of information rather than their own profession and that the students might develope unintended learning outcomes in this direction as some participants considered the teaching profession worthless. It was also seen that teachers were guiding students according to the needs of the age and their own viewpoints mainly because of the financial gain of a job rather than students' own preferences in professional sense.

School culture: This sub-theme emphasizes the verbal and nonverbal (such as visual and spiritual values) reactions of the teachers towards the items that form the identity of the school (its history, symbols, and unique qualities). In this respect, some of the participants expressed that they directed students to school activities in lessons $(n=5)$ and had them prepare logos, brochures and videos for the presentation of the school $(n=2)$. With reference to these findings, the opinion of the teacher T5 is as follows:

\footnotetext{
"Our school is a successful and renowned school. So there is a successful athmosphere at school. It ranks among the top three in our city... It has an important place not only in academic achievement but also in fields like sports and art. Everyone, families and teachers are aware of this... Under these circumstances, students are impressed by this situation is, even as a teacher I am impressed, too... Teachers are trying to maintain this athmosphere... In fact, the school atmosphere has an impact on the students. Therefore, I make students who are new to the secondary school do activities that I can introduce our school in order that they enjoy this air. For example, I once got the logo that best symbolized our school to all classes. I made them create a video about the school in Proshow programme. We organized a contest on our website and gave a small prize to the most voted one."
}

Based on this explanation, it is seen that computer software is used as a tool in adopting the school identity. Besides, some of the teachers stated that they aimed to make students adopt the school $(n=3)$ and to increase their sense of belonging $(n=2)$ by means of the student activities that they planned. Statements from the teachers who support this explanation are as follows:

"I always try to make an example activity about my school while having students practice... Some students come up with very qualified and beautiful works... I want them to know our school, every school has a system and a success. It has a different aspect from other schools. Students need to adopt the school and understand this." (T6)

"I want students to participate in contests or something else, as long as I have time. If we had a project and success about information technologies at our school, it would be great." (T11) 


\title{
48 EVALUATION OF INFORMATION TECHNOLOGIES TEACHERS' IN-CLASS BEHAVIOURS IN THE CONTEXT OF HIDDEN CURRICULUM
}

\begin{abstract}
"I'm talking about the success of our school düring lessons. We are a successful school, and your behaviors out of the school is also representative of our school. The director says this all the time... They are already proud that some of the children are in this school... This school adds values to students." (T13)
\end{abstract}

It is seen that the activities for creating a school culture are many more in schools that are successful and have a high vision than others. For example, the statements from two teachers are as follows:

\begin{abstract}
"We have basic principles and a vision: To be the best in any case, not only in the exam of TEOG (high school exam) but also in chess, futbol, volleyball and etc... There are no unsuccessful students, we aim to increase the success and to make students enter a good high school by reaching every student... The fact that the school has an organizational structure, increases the contribution of everyone." (T14)

"This school is not a very successful school... It is a suburb school to some extent... I do not make students do something about our school during practices much. It counts for nothing to the students even if I make them do school-related practices... Some of them look forward to the end of the lesson and going out." (T7)
\end{abstract}

In addition, the T12 coded teacher described the impact of school website and social networks on the adoption of school identity as follows:

\begin{abstract}
"The school website and facebook page are under my control because I am a computer teacher. I upload the announcements and the visuals on them... For our school, it is important to keep these platforms active. I always direct the students to follow these pages, it helps the student to be acquainted with our school much better. There is a school history on them. For example, we always upload photos, success stories and etc. We use the technology, in a sense, to disseminate the vision of the school to the students... I try to keep these areas active al the time. We announce the school's advertisements and successes here... I inform the students with regard to making contributions to these shares here... We publish successful students, classes, sports achievements and etc on the page. We reflect the successful identity of the school in this way."
\end{abstract}

The same teacher reported that he/she created a visitor book and suggestion box on the internet and that these people shared their opinions about the school. This demonstrates that the students' and other visitors' opinions are valued.

\section{Discussion, Conclusions and Reccomendations}

In this study, seven sub-themes for assessing the in-class behaviours and the factors affecting the emergence of these behaviours in the context of the hidden curriculum were determined on the basis of the opinions of the information technologies teachers. These themes were "power and authority", "prejudices and discrimination", "narratives", "communication", "role-model", "getting a profession" and "school culture". Similar dimensions were given place also in some other studies that showed the scope of the hideen curriculum (Johnson, Scholes \& Whittington, 2009; Mosalanejad, Ghobadifar \& Akbarzadeh, 2015; Mossop et al., 2013).

In the dimension of "power and authority", it was seen that most of the teachers wanted the students to be respectful, comply with the authority and obey the rules. Some of the teachers stated that they ignored the requests and opinions of the students and set up their own unwritten rules in the laboratory except for the written rules and they showed behaviours such as resigning the computers to the students, punishing the students that give any harm to the materials and making them keep watch in the laboratories at breaks. Rather than a democratic environment, it can be described as an authoritarian behaviour for the teacher to implement the rules that he/she set with respect to both the classroom layout and the use of the computers and apply to verbal violance. In such an environment, it can be said that the teacher is the one who talks, while the student is the one who listens. Consistent with these findings, in the study conducted by Filiz \& Doğar (2012), it was concluded in terms of the hidden curriculum, that teachers tried to make the pupils acquire such characteristics as being punctual, obeying the authority, being docile, taking responsibility, being successful and being respectful to statesmen. 
With respect to the hidden curriculum, Veznedaroğlu (2007) reported in his study that students learned that the administrators would behave them well, softly and understandinglwhen they obeyed the rules and that they would get angry with them and behave firmly when they did not obey. When it is taken into account that the hidden curriculum is shaped by the demands of the dominant classes in the society (Lynch, 1989), the formation of a hierarchy in the superior-subordinate relationship due to the teacher's putting a distance between themselves and students in the classroom setting can lead to unintended learning situations (Filiz \& Doğar, 2012). According to the neo-markist view, this situation in the school setting resembles the relationship between the boss and the employee in business life. Therefore, authoritarian and oppressive attitudes appears in teachers' attitudes toward the class and communication with the students (Anyon, 1981; Apple, 2004). In an environment where teacher-centered understanding prevails, learners learn to memorize the knowledge and they are away from autonomy and productivity. They can not express their feelings and thoughts easily. As a result passive, submissive, obedient and uncritical individuals are ggrown up. On the other hand, the fact that the students were sitting turning their back to the teacher due to the laboratory system, the computers' being a distracting entertainment tool for the students and the lack of grading value lead the students to act freely, not to take the teacher seriously and not to care about the lesson.

The dimension of "prejudices and discrimination" is related to the behaviors that teachers exhibit in a prejudiced and discriminatory manner according to certain characteristics of the students. Teachers expressed that they favoured the students who were more successful, more predisposed to information technologies and more obedient. These findings give clues about the hidden curriculum in contradiction with the concepts of equality, justice and democracy in the formal curriculum. In addition, some teachers in the study expressed that they favoured male students or the students who had an interest in sports and arts. Accordingly, students can learn that they will be appreciated and treated warmly and intimately by the teacher and that they will get a high mark in the course when they have those aforesaid features Çengel (2013) found that the performance grade given by the teachers were important for the students and therefore that the students wanted to win the teacher's favour and complimented them. Teacher behaviors differ according to the quality of life of the school and the socio-economic status of the students. While the teachers seem to be more interested in the students in schools with a high quality of life and socio-economic level, it is seen that the lessons are more superficial and teacher-centered in schools with a lower socio-economic level. The differences in the behaviors of teachers who work in the schools with different life quality can also be due to the expectations of the parents and administrators. Consistent with these findings, in Yildırm's (2013) study, it was concluded that the teachers working in the schools with lower socio-economic state conducted the lessons through traditional methods, they were too disciplined, they humiliated the students in front of their classmates and they regarded the students who were taking part in the lessons actively. In the same study, it was seen that in the schools with a higher socioeconomic state, the negative attitudes originating from the teacher were less than the ones in the other group. Indeed, in relation to the theme of "power and authority", the function of education is shaped by the economic level and the students are educated according to the existing structure of the society. This may lead teachers to have a discriminatory attitude due to certain differences among pupils, schools and parents (Apple, 2004; Giroux, 2011). Some studies came up with similar findings in relation to the hidden curriculum that arise from individual differences of students such as gender, socio-economic status, names, and ethnical origins (Akbulut, 2016; Elitok-Kesici, 2010; Saldıray \& Doğanay, 2017; Sarı \& Doğanay, 2009). The streotypes that individuals hold, along with historical, psycohological and sociocultural factors, may lead the individidual to display biased and discriminatory behaviours (Göregenli, 2012 p. 23). Stereotypes may prepare room for unintended reactions because of their immediate acceptance without requiring deep thinking as a cognitive shourtcut.

The dimension of "narratives" is associated with teachers' unplanned discourses and reactions about ethical and ideological issues beside those about social and historical values. The "narratives" theme is examined under two sub-dimensions as "social and moral" and "ideological". Based on the teachers' opinions, it was identified that they gave messages and made narratives more about social and moral values. The activities for values education are 


\section{EVALUATION OF INFORMATION TECHNOLOGIES TEACHERS' IN-CLASS BEHAVIOURS IN THE CONTEXT OF HIDDEN CURRICULUM}

stated in the formal curriculum, on which the cognitive field is of primary importance. These activities are based on reading from coursebooks and discussions and narratives in the classroom setting (Doğanay \& Sarı, 2004). However, since it is difficult to adopt the values with their cognitive dimension as written on the formal curriculum, it is necessary to focus on the hidden curriculum where the emotional dimension is taken into account (Akman, Çarşanbalı \& Alagöz, 2017; Tuncel, 2008; Yeşilyurt \& Kurt, 2011). In the study, some of the teachers emphasized that they talked about their and others' life stories and experiences, showed the students short videos and movies, warned them and directed them to cultural events. Real-life experiences, the media and communication technologies can be used as effective tools in conveyance of messages related to values education in the context of hidden curriculum in education (Akman, Çarşanbalı \& Alagöz, 2017; Doğanay \& Sarı, 2004; Kuş, 2009). It can be claimed that the real life experiences in which the emotional factors are taken into consideration in accordiance with the hidden curriculum are more effective than the direct teaching in adoption of the moral and social values by students. With regard to the dimension of "ideological", it was found that teachers were involved in religious and political discourses. Teachers' reflection of their ideological tendencies is seen as a component of the hidden curriculum (Apple, 2004, p. 79; Yüksel, 2004). Teachers reflect their beliefs, values and opinions beside the formal curriculum in the class. In this sense, when this situation contradicts with the formal curriculum, an hidden curriculum is introduced.

In the dimension of "communication", the emphasis is on the unplanned activities which emerge from interrelations and verbal or nonverbal reactions of the teacher and the student with an aim to understand each others. Unplanned learning situations may occur while teachers are talking to students and communicating verbally or non-verbally (Akbulut, 2016; Previna, 2011). In this study, two sub-dimensions as "positive communication" and "negative communication" were identified in the light of teacher opinions. Teachers' opinions were found to be mainly related to the sub-dimension of "positive communication". In this sense, teachers expressed that they listened to students' requests and behaved them in a sincere and smiling manner. In addition, some of the teachers pointed out that they empathized with their students, addressed to them with their names, approached them as friends, attached importance to body language, and established eye contact. As a result, students may feel that they are valued and cared about. For the dimension of "negative communication", teachers mostly expressed that they were harsh and communicated with them by shouting. Negative communication with the student can lead to the development of negative tendencies in students such as fearing from the teacher, seeing themselves worthless, and not being able to express feelings and thoughts freely (Broeckelman-Post et al., 2016; Kearney, Plax \& Allen, 2002; Yüksel, 2004). However, some teachers also reported that they displayed behaviours such as humiliating and ignoring the students. It can be said that these findings are also related to the dimensions of "power and authority" and "prejudices and discrimination". In some studies, it was also revealed that teachers communicated with their students negatively by resorting to harsh manners containing verbal violence (Broeckelman-Post et al., 2016; Yıldırım, Akan \& Yalçı, 2016). This may be due to the fact that teachers behave too rigorously as a power indicator in order to ensure the classroom layout and to dominate over students.

The "role-model" dimension refers to teacher behaviours that set an example for students in relation to moral, ethical and societal values. In this study, it is an important finding that most of the teachers were criticizing themselves about being mostly negative role-models for students. Oral or non-verbal behaviors of teachers in the class can be a negative example when they are different from their practices in real life, which can lead to the emergence of unwanted learnings. It is another important finding in terms of the hidden curriculum that most of the teachers, themselves, did not act in accordiance with the principles of information ethics altough they warned the students about them. Thus, it can be said that the behaviors exhibited in daily life are inconsistent and contradictory with what was told in lesson. In the this piece of research, most of the teachers stated that some of their characteristics might be negative models for the students, while others stated that they might also be positive models with their positive sides. It can be claimed that students take their teacher as a role model according to the teacher's sincerity and honesty. At this point, 
students' feeling the teacher's behaviour and the mutual social relationship between them are viewed as significant (Özsoy-Yener, 2011). As a matter of fact, it may be said that teachers may be a good role-model in adoption of values by students. In the study conducted by Köse \& Demir (2014), it was seen that the students took their teachers as examples according to the values such as love, justice and tolerance rather than the academic knowledge that teachers had. In the same study, it was concluded that the stduents developed negative tendencies towards the teachers who were discriminating among students and had poor communication. Similarly, in Coşkun's (2016) study, it was seen that the education faculty students took their instructors as models and that the hidden curriculum stemming from instructors' behaviours was effective in the process of acquiring responsibility, respect, justice and professional ethics.

The "professional" dimension emphasizes unintended messages about teachers' praising their own branch, the teaching profession or other professions, regarding them as worthless or directing to any profession. Most of the teachers gave messages about the economic benefits of the field of information technologies. On the other side, while some teachers seemed to be directing the students to professions related to their field, the others stated that the teaching profession was worthless. It was observed that the teachers made professional guidance mostly according to economical conditions and put emphasis mostly on the importance of the field of informatics rather than the teaching profession itself. It can be argued that students may achieve unintended learnings because of the fact that participant teachers see the teaching profession as worthless. It was also seen that the teachers were guiding students professionally according to mainly the economical benefits along with the needs of the age and their own viewpoints rather than students' own preferences Unlike the findings of this research, in some researches it was concluded that the hidden curriculum contributed to the adoption of professional values and the acquisition of professional identity (Bandini et al., 2017; Haidet \& Stein, 2006; Karimi et al., 2014; Mossop et al., 2013; Tsang, 2011). However, it was seen that mainly students who were getting education or doing internship on the professional field constituted the study sample of those aforesaid studies.

In the dimension of "school culture", the emphasis is on teachers' verbal and non-verbal (such as visual and spiritual values) reactions related to the components that constitute the the school identity (its history, symbols, unique qualities and etc.). Some of the participants in the study stated that they directed the students to school activities in lessons and made them prepare logos, brochures and videos for presentation of the school. In addition, some of the teachers aimed to increase the students' adoption of the school and their sense of belonging to their school by the activities they wanted them to do. In this regard, students can experience hidden learning situations in relation to school culture. The influence of the school culture (Çengel, 2013; Demir, Kaya \& Metin, 2012), which is also evaluated within the context of the hidden curriculum beside the formal curriculum, is reflected in the behaviour of the administrators, students and teachers (Alemdar \& Köker, 2013). According to Wren (1999), symbolic components such as ceremonies at school, school newspaper, school yearbook, student uniforms and the school logo are among the factors that constitute the hidden curriculum. One of the important findings of the research is that the computer software and multimedia contents are used as tools in the adoption of the school identity. As a matter of fact, these contents serve to the emergence of the hidden curriculum arising from school culture (Adams, 2017; Edwards, 2015). Significantly, it is seen that the number of the activities to create the school culture are higher in successful and high-vision schools. Similar to this finding, in the study conducted by Aktaş (2016), it was inferred that the students in science high school perceived their schools as institutions that provided a good education for examinations.

When it is taken into account that students spend a large part of their time with their teachers at school, teachers may be good role-models for adoption of the values by the students. Therefore, it is primarily necessary for teachers to internalize the basic values themeselves to exhibit a democratic attitude in the classroom setting and to stay away from inconsistent and showy attitudes. At this point, emotional factors (such as love and trust) can be taken into account in terms of the interaction between the student and the teacher in the formation of the hidden curriculum. The teacher's behaviors that conflict with the formal curriculum and the unwanted learning of the students should be revealed and the necessary 


\section{EVALUATION OF INFORMATION TECHNOLOGIES TEACHERS' IN-CLASS BEHAVIOURS IN THE CONTEXT OF HIDDEN CURRICULUM}

precautions should be taken. In addition, sections and experiences from important people's lives can be presented in lessons by means of media and information technologies. Teachers must be at a position to guide the education and put the student in the center rather than an authoritarian role in the learning process. In compliance with the results obtained for the subdimension of "getting a profession", the professional guidance by teachers can be done more consciously considering the students' interests and wishes.

In this study, on the basis of the result that information technologies can carry messages about the hidden curriculum, interactive boards can be prepared for the school corridors for the adoption of school culture through these technologies and websites and social networks can be used more effectively in presenting school-related activities. Platforms (such as a visitor's book and a box of views) on which information is shared for stakeholders in the school (graduate, student, parent, etc.) can be created. In lessons related to information technologies, activities about the school identity (such as designing a school logo, organizing school photos and creating school or classroom promotional videos) can be done by using specific softwares or programs. When most of the stakeholders in the classroom or school are thought to be unaware of the hidden curriculum (Lavoie, 2006; Tezcan, 2005); the awareness to the hidden curriculum among preservice teachers, the teachers in service and administrators on duty may be increased with the consciousness-raising efforts of experts. The results that stem from the hidden curriculum may be utilized in curriculum development efforts. As the hidden curriculum was examined in terms of teacher behaviours in this present study, the other dimensions of the hidden curriculum (such as the physical environment, architecture and emotional characteristics) may be investigated in detail in psopective studies and diversity in collection of the data (such as opinions from students and administrators, making observations in the classrroom setting) may be ensured for those studies.

\section{References}

Adams, C. (2017). Technology's hidden curriculum and the new digital pharmakon. In J. Jagodzinski (Ed.), The precarious future of education: Risk and uncertainty in ecology, curriculum, learning, and technology. Basingstoke and New York: Palgrave MacMillan.

Adiay, S. (2011). Exploring the hidden curricula of the seventh years of elementary schools whose level of success' are different from the point of classroom environment. (Unpublished $\mathrm{PhD}$ dissertation), Sakarya University, Institute of Social Sciences, Sakarya.

Ahola, S. (2000). Hidden curriculum in higher education: Something to fear for or comply to? Paper presented at the innovations in Higher Education 2000 Conference.

Akbulut, N. (2016). Investigation of the relationship between university student's level of perceived hidden curriculum and perceived educational stress. (Unpublished MA dissertation), Sakarya University, Institute of Educational Sciences, Sakarya.

Akman, Ö. Kılıç-Çarşanbalı, Ç., \& Alagöz, B. (2017). Sosyal bilgiler öğretmenlerinin değer eğitiminde örtük programa yönelik görüşlerinin değerlendirilmesi. Ahi Evran Üniversitesi Kırşehir Eğitim Fakültesi Dergisi, 18(1), 701-720.

Aktaş, H. H. (2016). Students' views about and experiences at school: Investigating the role of cultural capital and hidden curriculum. (Unpublished MA dissertation), Middle East Technical University, Institute of Social Sciences, Ankara.

Alemdar, M. Y., \& Köker, N. E. (2013). Öğrencilerin okul kültürü algısı üzerine amprik bir araştırma: Ege üniversitesi iletişim fakültesi örneği. Global Media Journal: Turkish Edition, 3(6), 230-261.

Alsubaie, M. A. (2015). Hidden curriculum as one of current issue of curriculum. Journal of Education \& Practice, 6(33), 125-128.

Altman, D. G. (1991). Practical statistics for medical research. London. 
Altınkurt, Y., \& Yılmaz, K. (2011). Öğretmen adaylarının öğretmenlerin mesleki etik dışı davranışlar ile ilgili görüşleri. Mehmet Akif Ersoy Üniversitesi Eğitim Fakültesi Dergisi, 11 (22), 113-128.

Anderson, T. (2001). The hidden curriculum in distance education: An updated view. Change, 33(6), 28-35.

Anyon, J. (1981). Social class and school knowledge. Curriculum Inquiry, 11, 3-42.

Apple, M. W. (2004). Ideology and curriculum. Routledge Falmer, New York.

Bandini, J., Mitchell, C., Epstein-Peterson, Z. D., Amobi, A., Cahill, J., Peteet, J., Balboni, T., \& Balboni, M. J. (2017). Student and faculty reflections of the hidden curriculum: How does the hidden curriculum shape students' medical training and professionalization? American Journal of Hospice and Palliative Medicine, 34, 57-63.

Broeckelman-Post, M. A., Tacconelli, A., Guzmán, J., Rios, M., Calero, B., \& Latif, F. (2015). Teacher misbehavior and its effects on student interest and engagement. Communication Education, 65(2), 204.

Coşkun, N. (2016). The views of students of faculty of education and faculty members regarding teaching professional ethics values: Hidden curriculum while gaining professional ethics values (Unpublished MA dissertation), Adnan Menderes University, Institute of Social Sciences, Aydin.

Cotton, D., Winter, J., \& Bailey. I. (2013). Researching the hidden curriculum: intentional and unintended messages. Journal of Geography in Higher Education, 37(2), 192-203.

Creswell, J. (2012). Educational research: Planning, conducting, and evaluating quantitative and qualitative research. Boston: Pearson Education.

Çengel, M. (2007). Curriculum evaluation of elemantary school fourth grade's computer and information technologies course (Unpublished MA dissertation), Adnan Menderes University, Institute of Social Sciences, Aydın.

Çengel, M. (2013). Hidden curriculum while constructing classroom climate: A research on vocational schools. (Unpublished $\mathrm{PhD}$ dissertation), Adnan Menderes University, Institute of Social Sciences, Aydin.

Çobanoğlu, R., \& Engin-Demir, C. (2014). The visible side of the hidden curriculum in schools. Elementary Education Online, 13(3), 776-786.

Çubukçu, Z. (2012). İlköğretim öğrencilerinin karakter eğitimi sürecinde örtük programın etkisi. Kuram ve Uygulamada Eğitim Bilimleri Dergisi, 12 (2), 1513-1534.

Demir, Ö., Kaya, H. İ., \& Metin, M. (2012). Lise öğrencilerinde okul kültürünün bir öğesi olarak okul yaşam kalitesi algısının incelenmesi. Pegem Ĕ̈itim ve Öğretim Dergisi, 2(4), 9-28.

Dickerson, L. (2007). A postmodern view of the hidden curriculum. (Unpublished PhD dissertation), Georgia Southern University.

Doğanay, A., \& Sarı, M. (2004). İlköğretim ikinci kademe öğrencilerine temel demokratik değerlerin kazandırılma düzeyi ve bu değerlerin kazandırılması sürecinde açı ve örtük programın etkilerinin karşılaştırılması. Kuram ve Uygulamada Eğitim Yönetimi, 10(39), 356-383.

Dreeben, R. (1968). On what is learned in schools. Reading, Mass: Addison-Wesley.

Dursun, D., \& Saraçoğlu, A. S. (2016). Bilişim teknolojileri öğretmenlerinin kendi yeterlikleri ve uygulamadaki sorunlar hakkındaki görüşlerinin değerlendirilmesi. The Journal of International Lingual, Social and Educational Sciences, 2(2), 40-58. 


\section{EVALUATION OF INFORMATION TECHNOLOGIES TEACHERS' IN-CLASS BEHAVIOURS IN THE CONTEXT OF HIDDEN CURRICULUM}

Edwards, R., \& Carmichael. P. (2012). Secret codes: The hidden curriculum of semantic web technologies. Discourse: Studies in the Cultural Politics of Education, 33(4), 575-590.

Edwards, R. (2015). Software and the hidden curriculum in digital education. Pedagogy, Culture \& Society, 23(2), 265-279.

Elitok-Kesici, A. (2010). The characteristics of the hidden curriculum used by secondary education teachers in the in- class communication. (Unpublished PhD dissertation), Adnan Menderes University, Institute of Social Sciences, Aydin.

Engin-Demir, C., Kılıı̧, A. Z., Çalışkan, B., Hanbay-Çakır, E., Güney-Karaman, N., \& Özbek, Ü. Ş. (2016). Okulların toplumsal cinsiyete duyarlılık açısından değerlendirilmesi başlangıç durum değerlendirmesi ve ihtiyaç analizi raporu. Eğitimde Toplumsal Cinsiyet Eşitliğinin Geliştirilmesi Projesi.

Filiz, B., \& Doğar, Y. (2012). Evaluation of the physical education teachers behaviors in terms of hidden program in the light of students' views. Sakarya Üniversitesi Eğitim Fakültesi Dergisi, $23,21-50$.

Frankel, R. M., \& Devers, K. J. (2000). Study design in qualitative research-1: Developing questions and assessing resource needs. Educ Health (Abingdon), 13(2), 251-261.

Giroux, H. A. (2011). On critical pedagogy. London: Continuum.

Göregenli, M. (2012). Temel kavramlar: önyargı, kalıpyargı ve ayrımcllk. İçinde K. Çayır and M. A. Ceyhan (Ed.), Ayrımcllık çok boyutlu yaklaşımlar (ss. 17-27), İstanbul: Bilgi Üniversitesi Yayinları.

Haidet, P., \& Stein, H. F. (2006). The role of the student-teacher relationship in the formation of physicians. The hidden curriculum as process. Journal of General Internal Medicine, 21 (Suppl 1), $16-20$.

Hafferty, F. W., \& O’Donnell, J. F. (2014). The hidden curriculum in health professional education. Hanover, NH: Dartmouth College Press.

Hafferty, F. W., Gaufberg, E. H., \& O’Donnell, J. F. (2015). The role of the hidden curriculum in "on doctoring" courses. AMA J Ethics, 17, 130-139.

Hafferty, F. W., \& Gaufberg, E. H. (2017). The hidden curriculum. A practical guide for medical teachers (5th edition). Edited by: Harden M. R., Dent A. J. Edinburgh: Churchill Livingstone.

Hopkins, L., Saciragic, L., Kim, J., \& Posner, G. (2016). The hidden curriculum: Exposing the unintended lessons of medical education. Cureus, 8(10), 1-11.

Hubbard, B. (2010). Manifestations of hidden curriculum in a community college online opticianry program: An ecological approach. (Unpublished $\mathrm{PhD}$ dissertation), Nottingham University. Available from ProQuest Dissertations \& Theses database (UMI No.3425631).

Gair, M. (2003). Socrates never took attendance: Hidden Curricula in a teacher preparation program. (Unpublished PhD Dissertation), Arizona State University.

Jackson, P. W. (1968). Life in classrooms. New York: Holt, Rinehart \& Winston.

Johnson, G., Scholes, K., \& Whittington, R. (2009). Fundamentals of Strategy. Harlow: Pearson Education.

Karakuş, M., Çoşğun, Ü. Ç., \& Lal, İ. (2015). Ortaokul bilişim teknolojileri ve yazilım dersi öğretim programının öğretmen görüşleri doğrultusunda incelenmesi. Turkish Studies International Periodical for the Languages, Literature and History of Turkish or Turkic, 10(11), 461-486. 
Karanxha, Z., Agosto, V., \& Bellara, A. P. (2013). The hidden curriculum: Candidate diversity in educational leadership preparation. Journal of Research on Leadership Education, 9, 34-58.

Karasar, N. (2012). Bilimsel araştırma yöntemleri (24. baskı). Ankara: Nobel Yayınları.

Karimi, Z., Ashktorab, T., Mohammadi, E., \& Abedi, H. A. (2014). Using the hidden curriculum to teach professionalism in nursing students. Iran Red Crescent Med. J., 16(3), e20319.

Kearney, P., Plax, T. G., \& Allen, T. H. (2002). Understanding student reactions to teachers who misbehave. In J. L. Cheseboro \& J. C. McCroskey (Eds.), Communication for teachers (pp. 127149). Boston, MA: Allyn \& Bacon.

Köse, M., \& Demir, E. (2014). Öğretmenlerin rol modelliği hakkında öğrenci görüşleri. Uluslararası Sosyal ve Ekonomik Bilimler Dergisi, 4(1), 8-18.

Kuş, D. (2009). Analysis of primary school curricula, hidden curriculum and out-of-school-sources about gaining values according to 8th grade school students and teachers opinion. (Unpublished MA dissertation), Ylldı Technical University, İstanbul.

Lavoie, R. (2006). It's so much work to be your friend: Helping the child with learning disabilities find social success. Association for Childhood Education International.

Leask, B. (2015). Internationalizing the curriculum. Oxon: Routledge.

Lynch, K. (1989). The hidden curriculum: Reproduction in education, a reappraisal. London: The Flamer Press.

Mosalanejad, L., Ghobadifar, M. A., \& Akbarzadeh, A. (2015). Untold aspects of hidden curriculum from teachers' experiences: A qualitative study. Journal of Research in Medical Education \& Ethics, 5(2), 106-114.

Mossop, L., Dennick, R., Hammond, R., \& Robbe, I. (2013). Analysing the hidden curriculum: Use of a cultural web. Medical Education, 47,134-43.

Murphy, L., Mufti, E., \& Kossem, D. (2009. Education studies: An introduction. Maidenhead: Open University Press.

Nelsen, R. W. (1981). Reading, writing, and relationships: Toward over coming the hidden curriculum of gender, ethnicity, and socio-eco nomic class. Interchange,12(2/3), 229-242.

Özsoy-Yener, F. (2011). The importance of administrators and teachers' role model behaviours on the solutions of students' negative acts. (Unpublished MA dissertation), Kocaeli University, Institute of Social Sciences, Kocaeli.

Pelit, E., \& Güçer, E. (2006). Öğretmen adaylarının öğretmenlik mesleğiyle ilgili etik olmayan davranışlara ve öğretmenleri etik dışı davranışa yönelten faktörlere ilişkin algılamaları. Ticaret ve Turizm Ĕ̈itim Fakültesi Dergisi, 2, 95-119.

Previna, D. S. (2011). Hidden in plain view: Classroom space, teacher agency and the hidden curricula. (Unpublished $\mathrm{PhD}$ dissertation), Harvard University, Graduate School of Education. Retrieved from UMI/ProQuest (UMI 3486009).

Saldıray, A., \& Doğanay, A. (2017). Örtük programda toplumsal cinsiyet: Bir ilkokulun örtük programinda toplumsal cinsiyete ilişkin nitel bir çalş̧ma. Turkish Studies International Periodical for the Languages, Literature and History of Turkish or Turkic, 12(25), 671-704.

Sarı, M., \& Doğanay, A. (2009). İnsan onuruna saygı değerinin kazandırılmas ında örtük program: Düşük ve yüksek okul yaşam kalitesine sahip iki ilköğretim okulunda nitel bir çalışma. Kuram ve Uygulamada Ĕ̈itim Bilimleri, 9(2), 877-940. 


\section{EVALUATION OF INFORMATION TECHNOLOGIES TEACHERS' IN-CLASS BEHAVIOURS IN THE CONTEXT OF HIDDEN CURRICULUM}

Skelton, A. (1997). Studying hidden curricula: Developing a perspective in the light of postmodern insights. Curriculum Studies, 5, 177-193.

Sönmez, V. (2008). Karşı program. Eurasian Journal of Educational Research, 30, 99-115.

Tezcan, M. (2003). Gizli müfredat eğitim sosyolojisi açısından bir kavram çözümlemesi. Türk Ĕğitim Bilimleri Dergisi, 1(1).

Tezcan, M. (2005). Sosyolojik kuramlarda eğitim. Ankara: Anı Yayıncılık.

Tsang A. (2011). Students as evolving professionals: Turning the hidden curriculum around thro ugh the threshold concept pedagogy. Transformative Dialogues: Teaching \& Learning Journal, 4(3), $1-11$.

Tuncel, İ. (2008). The hidden curriculum in terms of development of affective characteristics. (Unpublished PhD dissertation), Hacettepe University, Institute of Social Sciences, Ankara.

Uzgur, B. Ç., \& Aykaç, N. (2016). Bilişim teknolojileri ve yazılım dersi öğretim programının öğretmen görüşlerine göre değerlendirilmesi (Ege bölgesi örneği). Mustafa Kemal Üniversitesi Sosyal Bilimler Enstitüsü Dergisi, 13(34), 273-297.

Veznedaroğlu, R. L. (2007). The hidden curriculum in school and class (the case of a private primary school). (Unpublished PhD dissertation), Ankara University, Institute of Educational Sciences, Ankara.

Wren, D. J. (1999). School culture: Exploring the hidden curriculum. Adolescence, 34(135), 593-596.

Yüksel, S. (2004). Örtük program: Eğitimde saklı uygulamalar. Ankara: Nobel Yayınc1lı.

Yüksel, S. (2005). Kohlberg ve ahlâk eğitiminde örtük program: Yeni ilköğretim programlarında yer alan ahlâkî değerleri kazandırma için bir açılım. Kuram ve Uygulamada Eğitim Bilimleri, 5 (2), 307-338.

Yeşilyurt, E., \& Kurt, İ. (2012). Değerleri kazandırmasındaki etkililik açısından resmi ve örtük program ile okul dışı etmenlerin öğrenci görüş̧leri doğrultusunda değerlendirilmesi. International Periodical For The Languages, Literature and History of Turkish or Turkic,7(4), 3253-3272.

Ylldırm, F. (2013). The hidden curriculum in primary schools and the stress perception of primary school students created by the hidden curriculum. (Unpublished PhD dissertation), Firat University, Institute of Educational Sciences, Elazığ.

Yıldırım, A., \& Şimşek, H. (2016). Sosyal bilimlerde nitel araştırma yöntemleri (10. baskı). Ankara: Seçkin Yayıncilik.

Yildırım, I., Akan, D., \& Yalçın, S. (2016). Teacher behavior unwanted according to student's perceptions. International Education Studies, 9(11), 1-12. 